\title{
A review and update
}

A
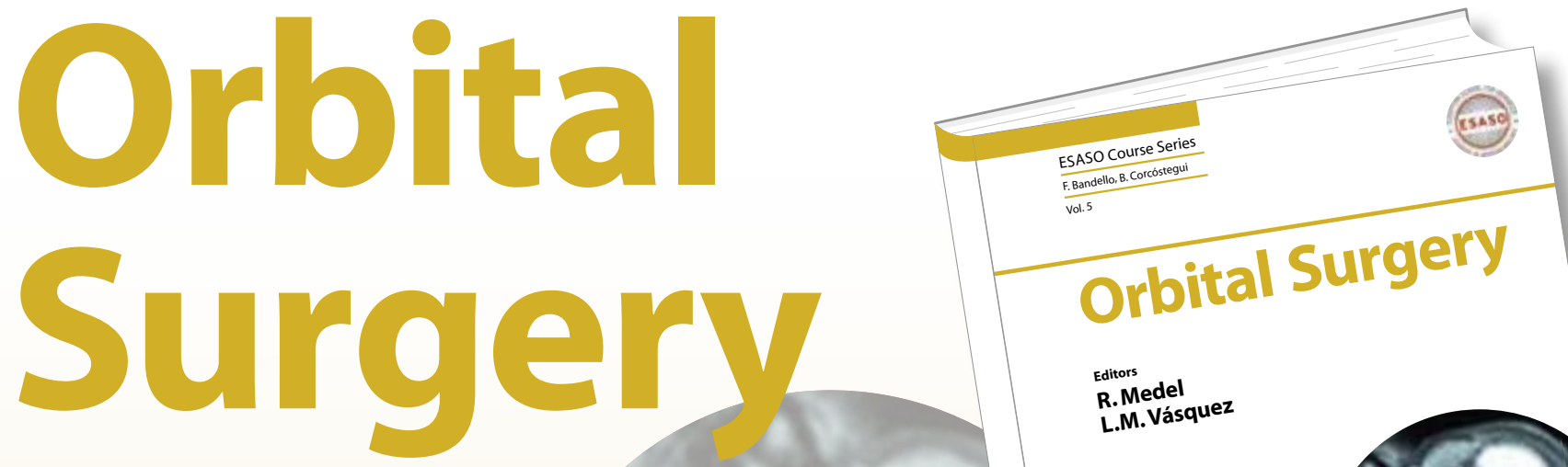

Editors

Ramón Medel

Luz Maria Vásquez

Orbital surgery deals with a variety of complications occurring in the eye socket comprising inflammatory diseases like thyroid-associated orbitopathy, tumors, infections, and injuries from trauma that affect eye function.

In this volume, renowned European orbital surgery experts share their professional experience and expertise. Their contributions cover basic as well as more specialized up-to-date concepts that are beneficial in the diagnosis and treatment of patients with orbital disorders.

The book offers a practical review of this complex and very interesting branch of ophthalmic plastic surgery for ophthalmology residents, ophthalmic plastic and orbital surgery fellows, ophthalmic plastic surgeons with a special interest in orbital surgery, and general ophthalmologists.

ESASO Course Series

\section{Vol. 5: Orbital Surgery}

Editors: Medel, R. ; Vásquez, L.M. (Barcelona) VIII + 116 p., 87 fig., 82 in color, 3 tab., 2014 CHF 98.00 / EUR 82.00 / USD 115.00 (soft cover) CHF 118.00 / EUR 98.00 / USD 138.00 (online) ISBN 978-3-318-02605-4 (soft cover) e-ISBN 978-3-318-02606-1
Fields of Interest: Ophthalmology; Surgery, Oncology, Plastic Surgery, Prosthetics

www.karger.com/esaso

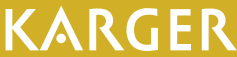

\section{Contents}

Preface: Medel, R.; Vásquez, L.M.

Basic Concepts in Orbital

Examination: Vásquez, L.M.

\section{Orbital Decompression in}

Thyroid Eye Disease: Baldeschi, L.;

Boschi, A.

\section{Orbital Fractures and}

Management of Diplopia:

Morax, S.; Bok-Beaube, C.

Approach to Diagnosis of Orbital

Tumours: Medel, R.; Balaguer, Ó.

Evisceration, Enucleation and

Exenteration: Tyers, A.G.

\section{Anophthalmic Socket:}

Hintschich, C.

Subject Index 


\title{
Expert presentations made available in print
}

\section{ESASO Course Series}

\author{
Series Editors \\ F. Bandello (Milan) \\ B. Corcóstegui (Barcelona)
}

ISSN 1664-882X (Print)

e-ISSN 1664-8838 (Online)

This new book series makes the essentials of the courses of the European School for Advanced Studies in Ophthalmology (ESASO) available to interested ophthalmologists, optometrists, technicians and residents all over the world. The presentations of the courses are published regularly featuring a wide range of ophthalmological topics from vitreoretinal pathology to retinal surgery, retinal diseases, cornea and refractive surgery or cataract.

The European School for Advanced Studies in Ophthalmology (ESASO) was founded in 2008 to address the need of master's degree programmes as well as the specific further education requirements of training and practicing clinicians, drawing on the skills of ophthalmologists worldwide and the support of various universities.

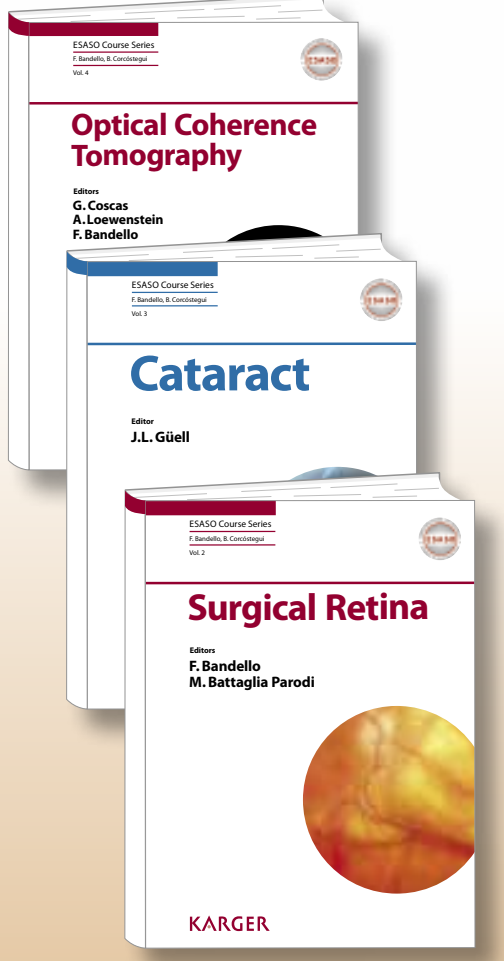

www.karger.com/esaso
Vol. 4: Optical Coherence Tomography Editors: Coscas, G. (Créteil/Paris); Loewenstein, A. (Tel Aviv); Bandello, F. (Milan) XII + 134 p., 137 figures, 97 in color, 9 tables, 2014

CHF 98.00 / EUR 82.00 / USD 115.00 (soft cover) CHF 118.00 / EUR 98.00 / USD 138.00 (online) ISBN 978-3-318-02563-7 (soft cover) e-ISBN 978-3-318-02564-4

\section{Vol. 3: Cataract}

Editor: Güell, J.L. (Barcelona)

VIII + 140 p., 178 fig., 168 in color, 5 tab., 2013 CHF 98.00/ EUR 82.00 / USD 115.00 (soft cover) CHF 118.00 / EUR 98.00 / USD 138.00 (online) ISBN 978-3-318-02410-4 (soft cover) e-ISBN 978-3-318-02411-1

Vol. 2: Surgical Retina

Editors: Bandello, F.; Battaglia Parodi, M. (Milan) $X+178$ p., 89 fig., 56 in color, 23 tab., 2012 CHF 98.00/ EUR 82.00 / USD 115.00 (soft cover) CHF 118.00 / EUR 98.00 / USD 138.00 (online) ISBN 978-3-318-02158-5 (soft cover) e-ISBN 978-3-318-02159-2

Online version for institutional purchase Prices subject to change EUR price for Germany, USD price for USA and Latin America only

To be ordered through:

\section{Order Form}

\section{ESASO Course Series}

Please send:

copy/ies: Vol. 5: Orbital Surgery

CHF 98.00 / EUR 82.00 / USD 115.00 (soft cover) ISBN 978-3-318-02605-4

copy/ies:

\section{ISBN 978-3-318-}

the book series ESASO Course Series on continuation beginning with vol.

All Karger series are available on continuation. Each volume will be sent upon publication until order is countermanded.

For easy ordering or further information about the series log on to: www.karger.com/esaso

\section{Payment:}

Postage and handling free with prepayment

Please charge this order to my credit card

\section{American Express Diners}

Visa MasterCard

Card No.:

Exp. date:

CVV/CVC:

Check enclosed Please bill me

Name/Address (please print):

E-Mail:

Date/Signature

Orders can be placed at agencies, bookstores, directly with the publisher, or with any Karger distributor.

S. Karger AG, P.O. Box, 4009 Basel (Switzerland) f: +41 6130612 34, e: orders@karger.com USA: S. Karger Publishers, Inc., 26 West Avon Road, P.O. Box 529, Unionville, CT 06085

Toll free: $+1-800-828-5479$

Germany: S. Karger GmbH, 79095 Freiburg France: Enter \& Read, Albertine Luginbuhl, 75014 Paris

Japan: Karger Japan, Inc., Tokyo 105-0012 South East Asia, China and Taiwan:

Karger China, Beijing 100020 